\title{
Freezing of edible flowers: Effect on microbial anc antioxidant quality during storage
}

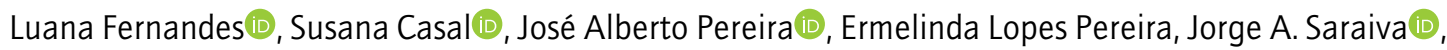 \\ and Elsa Ramalhosa (1)
}

\begin{abstract}
Edible flowers are a new gourmet product; however, they are not always available all years. Thus, it is essential to find out technologies to guarantee this product for a longer time. Flowers of four species (borage [Borago officinalis], heartsease [Viola tricolor], kalanchoe [Kalanchoe blossfeldiana], and dandelion [Taraxacum officinale]) were subjected to freezing (in their natural form and in ice cubes) and analyzed in terms of visual appearance, the content of flavonoids, hydrolysable tannins, phenolics, antioxidant activity (2,2-diphenyl-1-picrylhydrazyl radical scavenging activity and reducing power), and microbial quality after storage for 1 and 3 months. Flowers in ice cubes showed similar appearance to fresh ones during the 3 months of storage, whereas frozen flowers were only equivalent up to 1 month with the exception of kalanchoe. Even though flowers in ice cubes showed good appearance after 3 months of storage, they had the lowest values of bioactive compounds and antioxidant activity. On the contrary, when frozen, the content of bioactive compounds maintained or even increased up to 1 month of storage compared to fresh flowers, except for borage. Furthermore, in both freezing treatments, the microorganisms' counts decreased or maintained when compared to fresh samples, except in dandelion. In general, both treatments may allow keeping the flowers after their flowering times.
\end{abstract}

Keywords: antioxidant activity, edible flowers, frozen, ice cubes, microbial quality, storage

Practical Application: The market of edible flowers is increasing, although they are a very perishable product with short shelf-life. Edible flowers are stored in the cold (frozen or in ice cubes); however, the effect on the bioactive compounds and microbial quality that this treatment may have on borage (Borago officinalis), heartsease (Viola tricolor), kalanchoe (Kalanchoe blossfeldiana), and dandelion (Taraxacum officinale) flowers is unknown. So, the present study was conducted to increase the knowledge about the changes that freezing treatments may have in different edible flowers. The results of the present study underline that each flower has different behavior at frozen and ice cubes storage. However, freezing flowers maintain/increase the contents of bioactive compounds, while ice cubes not. Both treatments are effective in protecting flowers from microorganism growth. So, suggesting that both freezing treatments can be used as a preservative method and may allow keeping the flowers after their flowering times.

\section{INTRODUCTION}

Edible flowers are one of the new trends of food that are becoming popular among consumers and chefs gourmets. One of the reasons is that edible flowers affect the sensory characteristics of food by improving color, taste, and esthetic appearance (Mlcek \& Rop, 2011; Tanji \& Nassif, 1995). For example, borage (Borago officinalis L.) petals have a cucumber taste, and its stamens add a hint of sweetness; dandelion (Taraxacum officinale, Wiggers) has a

\footnotetext{
JFDS-2019-1851 Submitted 11/11/2019, Accepted 2/1/2020. Author Fernandes is with CIMO/School of Agriculture, Polytechnic Institute of Bragança, Campus de St ${ }^{a}$ Apolónia, Bragança, 5300-253,Portugal.LAQV@REQUIMTE/Laboratory of Bromatology and Hydrology, Faculty of Pharmacy, Porto University, Rua Jorge Viterbo Ferreira, 228, Porto, 4050-313, Portugal. LAQV-REQUIMTE, Department of Chemistry, University of Aveiro, Campus Universitário de Santiago, Aveiro, 3810-193, Portugal. Authors J.A. Pereira, E. Pereira, and Ramalhosa are with CIMO/School of Agriculture, Polytechnic Institute of Bragança, Campus de Sta Apolónia, Bragança, 5300-253, Portugal. Author Casal is with LAQV@REQUIMTE/Laboratory of Bromatology and Hydrology, Faculty of Pharmacy, Porto University, Rua Jorge Viterbo Ferreira, 228, Porto, 4050-313, Portugal. Author Saraiva is with Organic Chemistry, Natural Products and Agrifood (QOPNA) $\&$ LAQV-REQUIMTE, Department of Chemistry, University of Aveiro, Campus Universitário de Santiago, Aveiro, 3810-193, Portugal. Direct inquiries to authors Casal and Ramalhosa (E-mail: sucasal@ff.up.pt; elsa@ipb.pt).
}

sweet honey-like flavor; heartsease (Viola tricolor L.) has a slightly sweet green or grassy flavor, and kalanchoe (Kalanchoe blossfeldiana, Poelln.) flowers are sweet (Newman \& O'Conner, 2013). The other reason is an increase in the number of papers regarding the potential antioxidant of edible flowers (Barriada-Bernal et al., 2014; Benvenuti, Bortolotti, \& Maggini, 2016; Chen et al., 2015; Skowyra, Calvo, Gallego, Azman, \& Almajano, 2014; Xiong et al., 2014), reporting that flowers are rich in a great variety of natural antioxidants such as flavonoids, anthocyanins, and many other phenolic compounds related to health protection and improvement (Loizzo et al., 2016).

However, harvested flowers have short durability, and their seasonality of production requires preservation technologies. In the last years, new technologies have been applied to extend the shelflife and maintain the quality of edible flowers, such as high hydrostatic pressure (HHP) (Fernandes, Casal, Pereira, Ramalhosa, \& Saraiva, 2017a), edible coatings (Fernandes, Casal, Pereira, Pereira, et al., 2018; Fernandes, Pereira, et al., 2018), drying (Fernandes, Casal, Pereira, Saraiva, \& Ramalhosa, 2018), and irradiation (Koike et al., 2015). In particular, pansies treated with HHP maintained good appearance more 14 days than untreated and induced the production of bioactive compounds (Fernandes et al., 2017a). Concerning edible coatings, pansies increased shelf-life more 7 days than uncoated, and improved their physicochemical and 
microbiological quality (Fernandes, Casal, Pereira, Pereira, et al., 2018). Between drying methods, shade drying showed to be a promising process (more bioactive compounds formed and antioxidant activity) for centaurea petals (Fernandes, Casal, Pereira, Saraiva, et al., 2018). Irradiation induced higher antioxidant activity in Tropaeolum majus L. petals than the corresponding control (Koike et al., 2015). So, the quality was preserved (Koike et al., 2015). However, some of these new technologies are not yet applied by edible flower producers. The technologies most used by these are refrigeration, drying, crystallization, and freezing. Among these methods, freezing is one of the most common ways for maintaining the quality of fresh foods because it reduces the respiration rates and enzymatic activities and lowers the metabolic rates, extending product shelf life (Garcia \& Barrett, 2002). Frozen flowers are suitable to be used in bakery products and ice creams. Another option is to use flowers to make ice cubes, describing in several cookbooks (Cohen \& Fisher, 2012; Horrelson, 2003). In this form, they will add color, elegance, and flavor to beverages, such as cocktails, ice teas, water, juices, and alcoholic drinks. However, an impact on the nutrients and bioactive compounds levels and activity in frozen foods might occur along the storage time (Rickman, Barrett, \& Bruhn, 2007). Of our knowledge, no work has been performed on the effect of freezing on nutritional and bioactive compounds of borage, dandelion, kalanchoe, and heartsease flowers. So, the aim of this study was to evaluate for the first time the effect of freezing in these four edible flowers, as they are and in ice cubes, on their bioactive compounds (flavonoids, hydrolysable tannins, and total phenols determined by the total reducing capacity [TRC] assay), antioxidant activity (2,2-diphenyl-1-picrylhydrazyl [DPPH] scavenging activity and reducing power), and microbial quality during 1 and 3 months of storage $\left(-18^{\circ} \mathrm{C}\right)$. Thus, this work intends to provide more information to consumers and chefs gourmets, about the nutritional changes that occur in edible flowers treated with freezing methods along the storage, in order to increase the knowledge about until when they can store different species of flowers without compromising their nutritional and microbial quality. Furthermore, this information may also be necessary to food, cosmetic, and pharmaceutic industries that want to preserve edible flowers and then extract specific compounds.

\section{MATERIALS AND METHODS}

\subsection{Samples}

Fresh white borage (B. officinalis), heartsease ( $V$. tricolor), yellow kalanchoe (K. blossfeldiana), and dandelion ( $T$. officinale) flowers that were completely open were bought (100 g of each species) at a store specialized in edible flowers, located in Portugal. The production of flowers was based on organic system. The flowers were picked in the cool of the day (morning) to maintain the maximum flavor and taste. Furthermore, only flowers free of insect and disease were harvested. After harvest, flowers were cooled to maintain freshness. The fresh flowers were immediately transported to the laboratory under refrigeration.

\subsection{Preparation of ice cubes and freezing storage conditions}

Two freezing methods were studied in the present work, namely, the flowers were frozen in ice cubes and flowers were simply frozen (without water around them). The flowers were not sanitized before these treatments because they were bought at a store special- ized in edible flowers and the indication is that they are ready to eat.

For the first treatment, the edible flowers were placed in ice cubes trays (each cube with $3 \mathrm{~cm} \times 1.5 \mathrm{~cm}$, and with only one flower in each cube). Ultrapure water was added to about half of the tray full $(4 \mathrm{~mL})$, just enough to cover the flowers. They were placed in the freezer (P-Selecta, Templow), at $-18{ }^{\circ} \mathrm{C}$, until solidification, and then $4 \mathrm{~mL}$ of water was added until the cubes were full and frozen again. Ice cubes were stored under freezing $\left(-18{ }^{\circ} \mathrm{C}\right)(\mathrm{P}-\mathrm{Selecta}$, Templow). In the second method, portions of $10 \mathrm{~g}$ of each flower were put inside plastic bags and frozen at $-18{ }^{\circ} \mathrm{C}$ during the same time. The freezing temperature at $-18{ }^{\circ} \mathrm{C}$ was selected because it is the temperature usually used at home. The flowers subjected to both treatments were stored for 1 and 3 months. At each sampling time, the samples were thawed for 4 to $6 \mathrm{hr}$ in the refrigerator, in previously sterilized Petri dishes, because the ice cube water was subsequently analyzed. For each flower species, at each time and treatment, 45 to 60 flowers were used in the antioxidant analysis (triplicate); and 15 to 30 flowers were used for microbial analysis (triplicate) (approximately $50 \mathrm{~g}$ in total). The number of the flowers depended on the weight of each flower species, as the smaller ones (ex. borage), a higher number were needed.

\subsection{Visual appearance}

The visual quality of the flowers was measured by a score scale at different times of storage ( 1 day and 1 and 3 months), considering parameters of coloration, brightness, and turgescence. The score scale was based on a scale established to sunflowers by Nascimento, Paiva, Manfredini, and Sales (2019). The scale has scores from 1 to 4, namely:

Score 4: Flowers are turgid, bright, absence of spots-general aspect: good.

Score 3: Flowers are slightly wilted and opaque, appearance of dimming points—-general aspect: medium.

Score 2: Flowers are wilted and opaque, presence of dimming points - general aspect: bad.

Score 1: Flowers are totally wilted and dull, totally darkenedgeneral aspect: discard.

\subsection{Microbial quality}

The microbial qualities of the fresh flowers, of the water used to produce the ice cubes, of the ice cubes with frozen flowers, and of the frozen flowers (in their natural form) were analyzed after 1 and 3 months of storage $\left(-18^{\circ} \mathrm{C}\right)$. One gram of each sample was mixed with sterile peptone water solution and homogenized in a Stomacher 400 (Seward, West Sussex, UK). Decimal dilutions were prepared in the same diluent and plated on appropriate media in duplicate. The growth media and incubation conditions were the following for the studied microorganisms: (I) total mesophilic: Plate Count Agar (PCA, Merck, Algés, Portugal) for 2 days at $30^{\circ} \mathrm{C}$; (II) yeasts and molds: Rose Bengal Chloramphenicol Agar (RBC agar, Merck, Algés, Portugal) incubated at $27{ }^{\circ} \mathrm{C}$ for 5 days; and (III) total coliforms and Escherichia coli by the SimPlate ${ }^{\circledR}$ method. All counts were expressed as $\log _{10}$ colony forming units (CFU)/g sample.

\subsection{Extraction conditions for bioactive compounds analysis}

The extraction conditions used were those described by $\mathrm{Li}, \mathrm{Li}$, Li, Xu, and Xu (2014) and Fernandes, Pereira, Saraiva, Casal, and 


\begin{tabular}{|c|c|c|c|c|}
\hline \multirow[b]{2}{*}{$\begin{array}{l}\text { Storage } \\
\text { time }\end{array}$} & \multicolumn{4}{|c|}{ Visual appearance } \\
\hline & $\begin{array}{c}\text { Borage } \\
\text { (Borago officinalis) }\end{array}$ & $\begin{array}{c}\text { Dandelion } \\
\text { (Taraxacum } \\
\text { officinale) } \\
\end{array}$ & $\begin{array}{l}\text { Heartsease } \\
\text { (Viola tricolor) }\end{array}$ & $\begin{array}{c}\text { Kalanchoe } \\
\text { (Kalanchoe } \\
\text { blossfeldiana) }\end{array}$ \\
\hline Fresh & & & & \\
\hline $\begin{array}{l}\text { Scale } \\
\text { score }\end{array}$ & 4 & 4 & 4 & 4 \\
\hline 1 day & 8 & $\Rightarrow$ & & \\
\hline $\begin{array}{l}\text { Scale } \\
\text { score }\end{array}$ & 4 & 4 & 4 & 4 \\
\hline 1 month & & Q & & \\
\hline $\begin{array}{l}\text { Scale } \\
\text { score }\end{array}$ & 4 & 4 & 4 & 4 \\
\hline 3 months & $\approx$ & से & & \\
\hline $\begin{array}{l}\text { Scale } \\
\text { score }\end{array}$ & 4 & 4 & 4 & 4 \\
\hline
\end{tabular}

Figure 1-Visual appearance and scale score of borage, dandelion, heartsease, and kalanchoe in fresh and in ice cubes during storage $\left(-18{ }^{\circ} \mathrm{C}\right)$.

Ramalhosa (2019) with slight modifications. One gram of each flower (fresh or after thawing-frozen flowers and in ice cubes) was extracted with $10 \mathrm{~mL}$ of water:acetone $(6: 4, \mathrm{v} / \mathrm{v})$ at $37^{\circ} \mathrm{C}$ for 30 min under agitation $(900 \mathrm{rpm}$, IKA, RCT Model B, Staufen, Germany). The solution was filtered, and the final volume was adjusted to $10 \mathrm{~mL}$. The procedure was done in triplicate. The analyses were performed in fresh samples in order to simulate the real conditions when consumers are eating these flowers in drinks, ice creams, and cakes.

\subsection{Bioactive compounds (total flavonoids and hydrolyzable tannins)}

Total flavonoids and hydrolyzable tannins contents of the extracts of fresh, in ice cubes, and frozen flowers during 1 and 3 months of storage were determined following the methodologies used by Fernandes, Casal, Pereira, Ramalhosa, and Saraiva (2017b). The flavonoid contents were determined using $1 \mathrm{~mL}$ of extract solutions mixed with $3 \mathrm{~mL}$ of $\mathrm{NaNO}_{2}(5 \%, \mathrm{~m} / \mathrm{v})$ and $3 \mathrm{~mL}$ of $\mathrm{AlCl}_{3}(10 \%, \mathrm{~m} / \mathrm{v})$ after $5 \mathrm{~min}$. After $6 \mathrm{~min}, 2 \mathrm{~mL}$ of $\mathrm{NaOH}$ 


\begin{tabular}{|c|c|c|c|c|}
\hline \multirow{2}{*}{$\begin{array}{l}\text { Storage } \\
\text { time }\end{array}$} & \multicolumn{4}{|c|}{ Visual appearance } \\
\hline & $\begin{array}{c}\text { Borage } \\
\text { (Borago officinalis) } \\
\end{array}$ & $\begin{array}{c}\text { Dandelion } \\
\text { (Taraxacum officinale) }\end{array}$ & $\begin{array}{l}\text { Heartsease } \\
\text { (Viola tricolor) }\end{array}$ & $\begin{array}{c}\text { Kalanchoe } \\
\text { (Kalanchoe blossfeldiana) }\end{array}$ \\
\hline Fresh & & & & \\
\hline
\end{tabular}

Scale 4

score

1

month

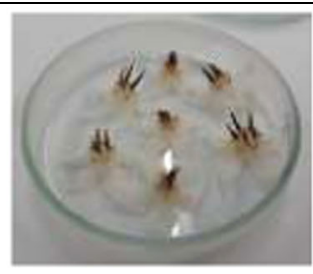

3

Scale

score

3

months

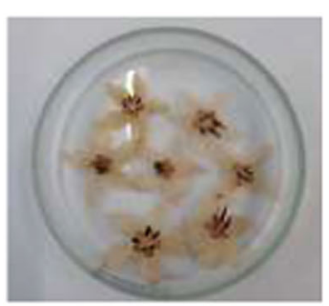

4

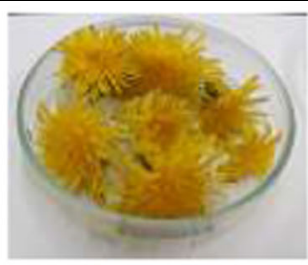

3

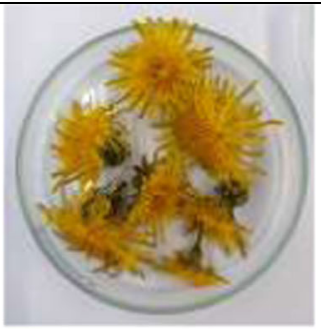

2
4

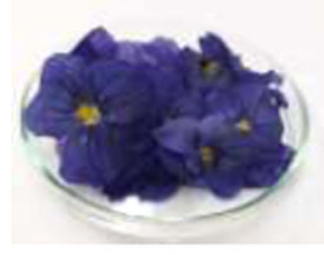

3

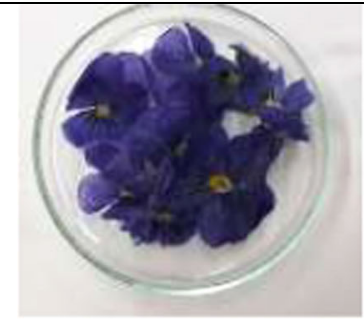

2
4

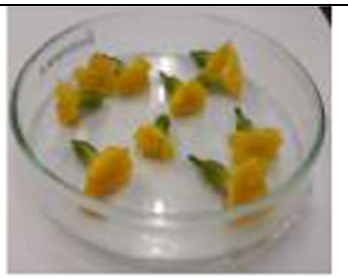

4

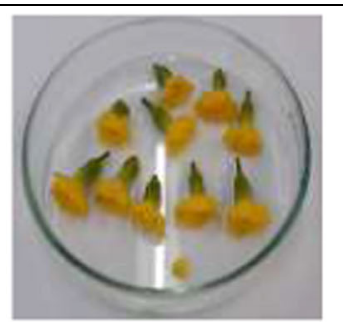

4

score

Figure 2-Visual appearance and scale score of borage, dandelion, heartsease, and kalanchoe in fresh and frozen in their natural form during storage $\left(-18^{\circ} \mathrm{C}\right)$.

(1 M) was also added. The measurement of absorbance was read at $510 \mathrm{~nm}$ and flavonoids were quantified using a standard curve of quercetin (10 to $160 \mu \mathrm{g} / \mathrm{mL}$ ). Concerning hydrolyzable tannins, $1 \mathrm{~mL}$ of different diluted extracts was mixed with $5 \mathrm{~mL}$ of $\mathrm{KIO}_{3}$ $(2.5 \%, \mathrm{~m} / \mathrm{v})$ and stirred. The absorbance was measured at $550 \mathrm{~nm}$ and a standard curve of tannic acid $(0.025$ to $1.6 \mathrm{~g} / \mathrm{L})$ was used for calibration. All measurements were performed in triplicate. The results for flavonoids were expressed in milligram of quercetin equivalent per gram fresh weight ( $\mathrm{mg} \mathrm{QE} / \mathrm{g} \mathrm{fw}$ ) and hydrolyzable tannins in milligram of tannic acid equivalent per gram fresh weight (mg TAE/g fw).

\subsection{Total reducing capacity}

The TRC of each sample was determined by the FolinCiocalteu method described by Falcão et al. (2017). A total of $8 \mathrm{~mL}$ of the extract solutions were added $500 \mu \mathrm{L}$ of Folin-Ciocalteu reagent. After 3 to $8 \mathrm{~min}, 1.5 \mathrm{~mL}$ of saturated sodium carbonate solution was added. After $2 \mathrm{hr}$, the absorbance values were read at $765 \mathrm{~nm}$. The blank and standards were prepared similarly, replacing the sample by the solvent used in the extraction and the standards, respectively. A calibration curve was obtained with gallic acid $(0.25$ to $5 \mathrm{mg} / \mathrm{L})$, and the results expressed in milligram of gallic acid equivalent per gram fresh weight (mg GAE/g fw).

\subsection{Antioxidant activity}

2.8.1 2,2-diphenyl-1-picrylhydrazyl radical scavenging activity. The DPPH radical scavenging activity was determined by the procedure described by Delgado, Malheiro, Pereira, and Ramalhosa (2010) with some modifications. The extract solutions were diluted with the solvent used for the extraction, and $300 \mu \mathrm{L}$ of these solutions were added to $2.7 \mathrm{~mL}$ of the DPPH methanolic solution $\left(6.09 \times 10^{-5} \mathrm{~mol} / \mathrm{L}\right)$. After $1 \mathrm{hr}$ in the dark at room temperature, absorbance was read at $517 \mathrm{~nm}$. The percentage of scavenging effect expressed the antioxidant activity according to Eq. 1:

$$
\begin{aligned}
& D P P H \text { radical scavenging effect }(\%)= \\
& \frac{A_{D P P H}-A_{\text {Sample }}}{A_{D P P H}} \times 100
\end{aligned}
$$

where $A_{D P P H}$ was the absorbance of the DPPH solution and $A_{\text {Sample }}$ was the absorbance in the presence of the sample. The blank was 

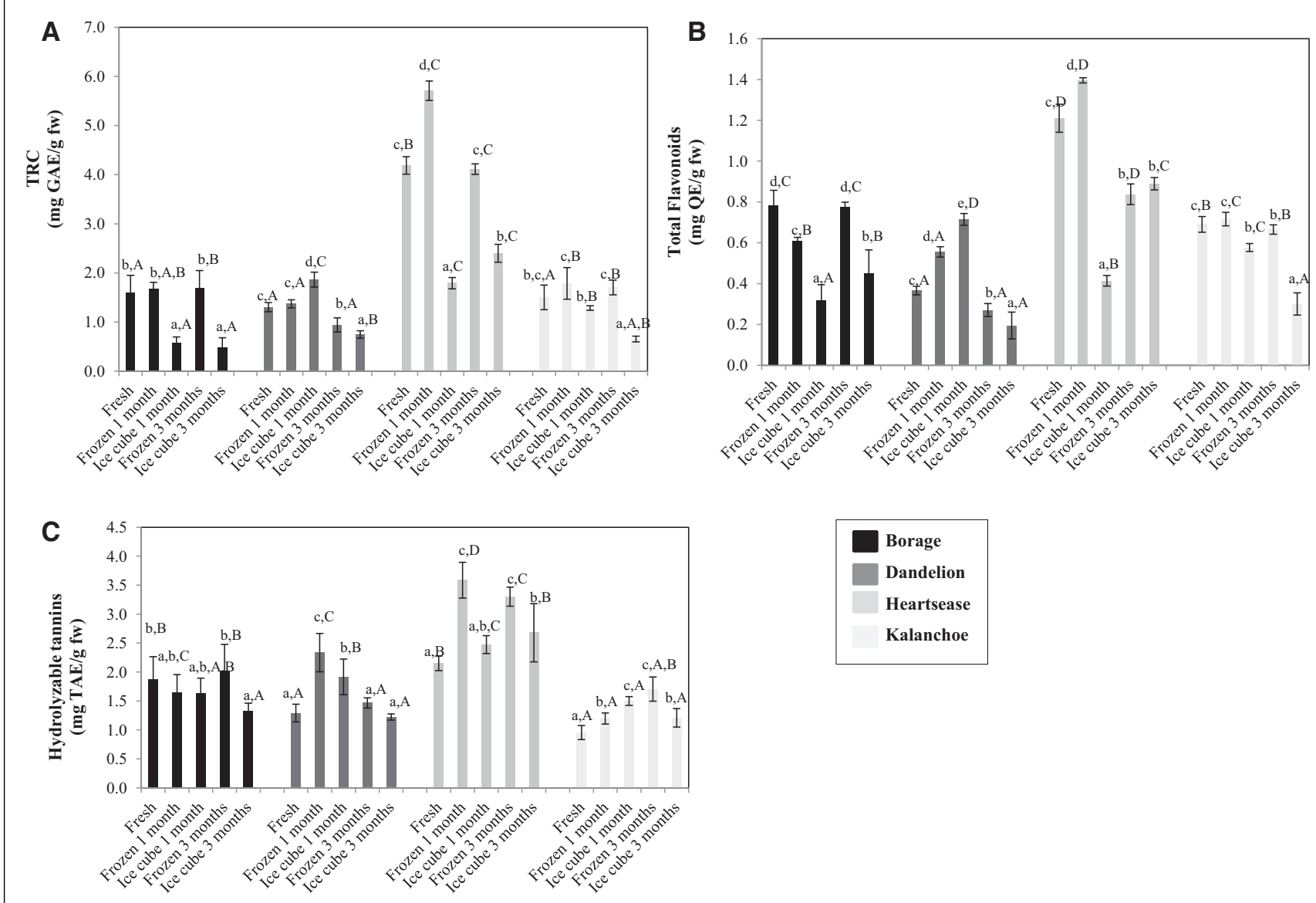

Figure 3-TRC, total flavonoids, and hydrolyzable tannins contents in fresh, frozen in their natural form, and ice cubes of four edible flowers during storage $\left(-18^{\circ} \mathrm{C}\right)$. Lowercase letters compared different treatments in the same flower species; uppercase letters compared flower species subjected to the same treatment.

made with the solution used in samples' extraction. The extract concentration providing $50 \%$ of DPPH radical scavenging effect $\left(E C_{50}\right)$ was calculated from the graph of DPPH radical scavenging effect percentage versus extract concentration.

2.8.2 Reducing power. The reducing powers of the extracts were determined by the procedure described by Delgado et al. (2010). A total of $1.0 \mathrm{~mL}$ of the extract solutions at different concentrations were added to $2.5 \mathrm{~mL}$ of phosphate buffer $0.2 \mathrm{M}$ (pH 6.6) and $2.5 \mathrm{~mL}$ of $\mathrm{K}_{3}\left[\mathrm{Fe}(\mathrm{CN})_{6}\right] 1 \%(\mathrm{~m} / \mathrm{v})$. After shaking, the mixture was incubated at $50{ }^{\circ} \mathrm{C}$ for $20 \mathrm{~min}$; and $2.5 \mathrm{~mL}$ of $10 \%$ trichloroacetic acid $(\mathrm{m} / \mathrm{v})$ was added with further stirring. A volume of $2.5 \mathrm{~mL}$ of the mixture was transferred to another test tube, to which $2.5 \mathrm{~mL}$ of distilled water and $0.5 \mathrm{~mL}$ of $\mathrm{FeCl}_{3} 0.1 \%(\mathrm{~m} / \mathrm{v})$ were added. The absorbance values were read at $700 \mathrm{~nm}$. From the graph $\mathrm{Abs}_{700 \mathrm{~nm}}$ versus extract concentration, the $\mathrm{EC}_{50}$ values were determined corresponding to the extract concentration that gave an absorbance of 0.5 .

\subsection{Statistical analysis}

The SPSS Statistical software, v. 18.0 (SPSS Inc., Chicago, IL), was used for the statistical treatment of the data. The normality of the data was verified by the Shapiro-Wilk test. Analysis of variance (ANOVA) or ANOVA Welch were carried out to determine if there were significant differences $(P<0.05)$ between samples, depending on the existence or not of homogeneity of variances, respectively. Additionally, if significant differences were detected between treatments, a post hoc analysis was performed, namely, the Tukey's honestly significant difference test (if variances in the different groups were identical) or Games-Howell test (if they were not). The homogeneity of the variances was tested by Levene's test.

\section{RESULTS AND DISCUSSION}

\subsection{Visual appearance}

Figure 1 and 2 show the visual appearance of fresh, in ice cubes, and frozen flowers (in their natural form) during storage. According to the scale score established, flowers in ice cubes showed good visual appearance without any signs of damage (score 4) until 3 months of storage (Figure 1), probably because the water around the flower protected them for physical and oxidative damage. However, borage, dandelion, and heartsease frozen samples only showed medium visual appearance (score 3) until 1 month of storage, because signs of wilted and dimming points were visible. After this period, some symptoms of chilling injury appeared in these three flower species. Mainly, borage showed signs of browning, and petals appeared as darkened translucent that will deteriorate rapidly after thawing. So, they were classified with a scale score equal to 1 . The tips of petals of dandelion became limp and dark, and the flower lost all its brightness (score 2). Heartsease presented some loss of texture and brightness, being limp and difficult to handle (score 2). On the contrary, frozen kalanchoe remained with good visual appearance, similar to fresh (score 4), 


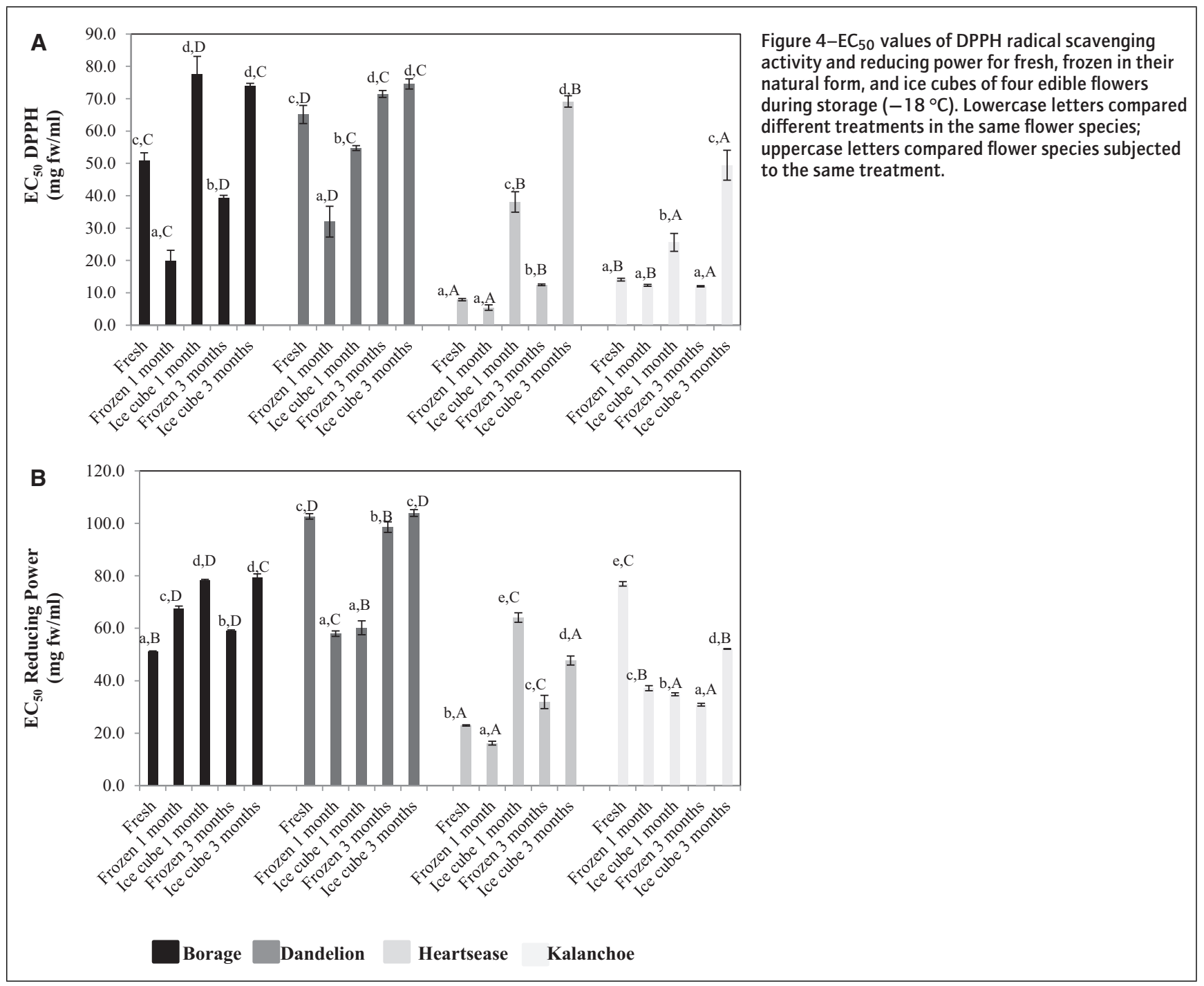

after 3 months of storage, probably because they have more rigid petals than the other flowers.

\subsection{Total reducing capacity, total flavonoids, and hydrolyzable tannins}

The content of bioactive compounds of fresh and defrosted flowers (in their natural form and in ice cubes) after 1 and 3 months of storage are presented in Figure 3A to C. Compounds with antioxidant activity are very important for keeping the quality of flowers because these substances delay the process of senescence and decay, which is caused by the action of reactive oxygen radicals on biomembranes (Panavas \& Rubinstein, 1998).

Comparing the four fresh flowers, the heartsease showed the highest values of TRC, total flavonoids, and hydrolyzable tannins. Regarding treatments, freezing and ice cubes modified the amounts of bioactive compounds in all edible flowers. However, no trend was observed between treatments and time of storage. In particular, ice cubes of borage and heartsease, during both times of storage, showed lower TRC and total flavonoids than fresh ones, while for dandelion and kalanchoe, this behavior was only observed after 3 months of storage. It seems plausible that the cellular structures brake with the freezing process, enabling lixiviation of some components into the water during the defrosting process.

When the flowers were frozen (in their natural form) and stored during 1 to 3 months, a significant decrease in TRC $(31 \%$ and $28 \%$ ) and total flavonoid (51\% and $40 \%$ ) contents was observed in dandelion and heartsease, respectively. In frozen kalanchoe (at both storage times), higher or similar values of all bioactive compounds were observed than in fresh. This fact could be attributed to some loss of water during the freezing process.

So, in general, flowers in ice cubes after 3 months of storage showed the lowest values of bioactive compounds with some few exceptions. Furthermore, it was observed that for all frozen flowers, the contents of phenolic compounds (TRC, tannins, and flavonoids) were kept or even increased during 1 month of storage except borage. The same tendency was also observed in other studies in plants, such as in fresh and frozen horseradish and lovage leaves, for which an increment of $15 \%$ and $0.5 \%$, respectively, was determined (Tomsone \& Kruma, 2014). These results can be explained by the fact that ice crystals formed within the plant matrix can rupture the cell structure, allowing the lixiviation of water-soluble cellular components into the drained water (Asami, Hong, Barrett, \& Mitchell, 2003), and therefore, these compounds can be transferred more easily into the extraction solution. 
Table 1-Mean counts \pm standard deviation $(\log \mathrm{CFU} / \mathrm{g})$ of total aerobic mesophilic, yeasts, molds, total coliforms, E. coli, and psychrotrophic bacteria examined in water, fresh flowers, flowers in ice cubes and frozen flowers during storage.

\begin{tabular}{|c|c|c|c|c|c|c|c|c|}
\hline \multicolumn{9}{|c|}{ Conditions } \\
\hline \multicolumn{2}{|c|}{ Samples } & Days & Total aerobic mesophilic & Yeasts & Molds & Total coliforms & E. coli & $\begin{array}{c}\text { Psychrotrophic } \\
\text { bacteria }\end{array}$ \\
\hline Water & & & $<2$ & $<2$ & $<2$ & $<1$ & $<1$ & $<2$ \\
\hline \multirow[t]{5}{*}{ Borage } & Fresh & 0 & $4.53 \pm 0.12^{\mathrm{d}}$ & $<2^{\mathrm{a}}$ & $<2^{\mathrm{a}}$ & $<1$ & $<1$ & $4.14 \pm 0.17^{\mathrm{b}}$ \\
\hline & Ice cube & 1 month & $<2^{\mathrm{a}}$ & $<2^{\mathrm{a}}$ & $<2^{\mathrm{a}}$ & $<1$ & $<1$ & $<2^{\mathrm{a}}$ \\
\hline & Frozen & & $4.00 \pm 0.01^{\mathrm{b}}$ & $<2^{\mathrm{a}}$ & $<2^{\mathrm{a}}$ & $<1$ & $<1$ & $<2^{\mathrm{a}}$ \\
\hline & Ice cube & 3 months & $<2^{\mathrm{a}}$ & $<2^{\mathrm{a}}$ & $<2^{\mathrm{a}}$ & $<1$ & $<1$ & $<2^{\mathrm{a}}$ \\
\hline & Frozen & & $4.15 \pm 0.01^{\mathrm{c}}$ & $<2^{\mathrm{a}}$ & $<2^{\mathrm{a}}$ & $<1$ & $<1$ & $2.19 \pm 0.24^{\mathrm{a}}$ \\
\hline \multirow[t]{5}{*}{ Dandelion } & Fresh & 0 & $5.69 \pm 0.14^{\mathrm{a}}$ & $2.48 \pm 0.40^{\mathrm{a}}$ & $2.23 \pm 0.15^{\mathrm{a}}$ & $<1$ & $<1$ & $4.68 \pm 0.09^{\mathrm{a}}$ \\
\hline & Ice cube & 1 month & $5.49 \pm 0.10^{\mathrm{a}}$ & $2.27 \pm 0.20^{\mathrm{a}}$ & $2.69 \pm 0.18^{\mathrm{b}}$ & $<1$ & $<1$ & $4.55 \pm 0.07^{\mathrm{a}}$ \\
\hline & Frozen & & $5.70 \pm 0.03^{\mathrm{a}}$ & $2.19 \pm 0.24^{\mathrm{a}}$ & $3.01 \pm 0.13^{\mathrm{c}}$ & $<1$ & $<1$ & $4.74 \pm 0.06^{\mathrm{a}}$ \\
\hline & Ice cube & 3 months & $5.64 \pm 0.09^{\mathrm{a}}$ & $2.67 \pm 0.26^{\mathrm{a}}$ & $3.19 \pm 0.06^{\mathrm{c}}$ & $<1$ & $<1$ & $4.57 \pm 0.11^{\mathrm{a}}$ \\
\hline & Frozen & & $6.44 \pm 0.36^{\mathrm{b}}$ & $2.35 \pm 0.40^{\mathrm{a}}$ & $3.50 \pm 0.14^{\mathrm{d}}$ & $<1$ & $<1$ & $4.72 \pm 0.15^{\mathrm{a}}$ \\
\hline \multirow[t]{5}{*}{ Heartsease } & Fresh & 0 & $5.32 \pm 0.04^{\mathrm{d}}$ & $<2^{\mathrm{a}}$ & $<2^{\mathrm{a}}$ & $<1$ & $<1$ & $4.68 \pm 0.10^{\mathrm{d}}$ \\
\hline & Ice cube & 1 month & $3.20 \pm 0.15^{\mathrm{a}}$ & $<2^{\mathrm{a}}$ & $<2^{\mathrm{a}}$ & $<1$ & $<1$ & $<2^{\mathrm{a}}$ \\
\hline & Frozen & & $4.75 \pm 0.06^{c}$ & $<2^{\mathrm{a}}$ & $<2^{\mathrm{a}}$ & $<1$ & $<1$ & $2.40 \pm 0.32^{\mathrm{b}}$ \\
\hline & Ice cube & 3 months & $3.56 \pm 0.16^{\mathrm{b}}$ & $<2^{\mathrm{a}}$ & $<2^{\mathrm{a}}$ & $<1$ & $<1$ & $<2^{\mathrm{a}}$ \\
\hline & Frozen & & $4.77 \pm 0.09^{c}$ & $<2^{\mathrm{a}}$ & $<2^{\mathrm{a}}$ & $<1$ & $<1$ & $3.06 \pm 0.18^{\mathrm{c}}$ \\
\hline \multirow[t]{5}{*}{ Kalanchoe } & Fresh & 0 & $6.67 \pm 0.08^{c}$ & $2.12 \pm 0.24^{\mathrm{a}}$ & $<2^{\mathrm{a}}$ & $<1$ & $<1$ & $5.44 \pm 0.03^{\mathrm{b}}$ \\
\hline & Ice cube & 1 month & $3.56 \pm 0.10^{\mathrm{a}}$ & $<2^{\mathrm{a}}$ & $<2^{\mathrm{a}}$ & $<1$ & $<1$ & $<2^{\mathrm{a}}$ \\
\hline & Frozen & & $3.53 \pm 0.19^{\mathrm{a}}$ & $<2^{\mathrm{a}}$ & $<2^{\mathrm{a}}$ & $<1$ & $<1$ & $2.08 \pm 0.15^{\mathrm{a}}$ \\
\hline & Ice cube & 3 months & $3.61 \pm 0.06^{\mathrm{a}}$ & $<2^{\mathrm{a}}$ & $<2^{\mathrm{a}}$ & $<1$ & $<1$ & $<2^{\mathrm{a}}$ \\
\hline & Frozen & & $3.95 \pm 0.11^{\mathrm{b}}$ & $<2^{\mathrm{a}}$ & $<2^{\mathrm{a}}$ & $<1$ & $<1$ & $<2^{\mathrm{a}}$ \\
\hline
\end{tabular}

Values with the same letter in the same column are not statistically different $(P>0.05)$.

Considering a frozen flower in its natural form and that in an ice cube, the first consists of freezing the water contained in the plant cell, while in ice cubes, two layers of water will freeze around the flower, protecting it. Therefore, it is expected that more ice crystals will be formed inside the flower tissue during freezing, which may induce a higher degree of cell wall damage (Petzold \& Moreno, 2016), releasing more bioactive compounds. However, when analyzing the solution released during thawing, no bioactive compounds were quantified.

\subsection{Antioxidant activity (DPPH radical scavenging activity and reducing power)}

The $\mathrm{EC}_{50}$ values of DPPH radical scavenging activity and reducing power for fresh, frozen, and in ice cubes for the four flowers studied in the present work are shown in Figure 4. As expected, fresh heartsease flowers showed the lowest values of $\mathrm{EC}_{50}$ for DPPH radical scavenging activity and reducing power, indicative of higher antioxidant activity, probably associated with the accumulation of phenolic compounds (ex. flavonoids and tannins) as mentioned in the previous section. In general, the four flowers in ice cubes showed the highest values of both $\mathrm{EC}_{50}$, indicative of lower antioxidant activity, probably because some water-soluble compounds may migrate from the flower to the solution. Regarding the frozen borage and dandelion flowers after 1 month of storage, they showed higher antioxidant potential (lower values of $\mathrm{EC}_{50}$ of $\mathrm{DPPH}$ ) than for other treatments and times. A similar increase of antioxidant activity was detected in frozen dandelion, heartsease, and kalanchoe after 1 month of storage for reducing power. In general, for the frozen samples, after 3 months of storage, high values of $\mathrm{EC}_{50}$ of $\mathrm{DPPH}$ were observed, indicative of low antioxidant activity. So, it was clear that a substantial proportion of the total antioxidant activity of the flowers may be lost during frozen storage. A similar decrease in the DPPH index during the frozen storage of some vegetables was also mentioned by Puupponen-Pimiä et al. (2003). In general, each flower showed a different behavior when subjected to different frozen methods (in natural form or ice cubes) and during storage time.

\subsection{Microbial quality}

The microbial quality of fresh, in ice cubes, and frozen flowers in their natural form is detailed in Table 1. The water used for preparing the ice cubes did not contain pathogenic bacteria (E. coli) that could remain viable during storage, as well as none of the microorganisms investigated (Table 1). So, water was not a vehicle of contamination. The water used for preparing ice must be free from solids, bacteria, flavors, odors, and dissolved minerals, must be at the lowest possible level (WHO, 1997), and should not contain pathogenic bacteria that could remain viable during storage (Dickens et al., 1985). Regarding fresh flowers, borage showed the lowest microorganisms counts, while kalanchoe had the highest values. In general, both freezing methods decreased or maintained the levels of microorganisms when compared to fresh samples. There was an exception regarding frozen dandelion, with higher counts of total aerobic mesophilic (3 months) and molds (at both storage times) than fresh flowers, as well as in ice cubes (at both storage times) for molds. In general terms, the low-temperature conditions used had a protective effect against the growth of some spoilage microorganisms and foodborne pathogens, and their counts decreased or remained less than $1 \mathrm{CFU} / \mathrm{g}$ (for total coliforms and E. coli) after storage in most of the flowers. In fact, mesophilic microorganisms may continue to grow at low temperature while at reduced growth rates (Vescovo, Torriano, Orsi, Macchiarolo, \& Scolari, 1996). The low counts of coliforms are a hygienic indicator and indicate sanitary conditions or proper hygiene practices during or after food production (Sousa, Tamagnini, Olmos, \& González, 2002).

Psychrotrophic microorganisms are able to grow at low temperatures (Gounot, 1986.); however, in the present study, it was not observed an increase in psychrotrophic bacteria counts along storage when compared to the fresh state. 
When comparing frozen flowers in ice cubes and in their natural form, the first freezing method resulted in flowers with a lower level of microbial contamination, probably because in ice cubes, the flowers were more protected from external contaminations than frozen flowers. Concerning storage time (1 and 3 months) for ice cubes, in most of the flowers, no significant differences were detected except for molds in dandelion and total aerobic mesophilic in heartsease. In both cases, higher storage times induced higher values of microorganisms. Frozen samples stored for 3 months had similar or higher values of total aerobic mesophilic than those stored for 1 month. Furthermore, in most situations, fresh, in ice cubes, and frozen flowers in their natural form presented an acceptable or satisfactory microbiological quality according to the limits established for the microorganism count at $30{ }^{\circ} \mathrm{C}\left(\leq 10^{4}\right.$ and $>10^{4} \leq 10^{6} \mathrm{CFU} / \mathrm{g}$, respectively $)$, molds ( $\leq 10^{2}$ and $>10^{2} \leq 10^{3} \mathrm{CFU} / \mathrm{g}$, respectively), and yeast $\left(\leq 10^{2}\right.$ and $>10^{2} \leq 10^{5} \mathrm{CFU} / \mathrm{g}$, respectively) for the ready to eat group (Santos, Correia, Cunha, Saraiva, \& Novais, 2005). The exceptions observed were: for frozen dandelion after 3 months and fresh kalanchoe regarding the total aerobic mesophilic; and frozen dandelion after 1 and 3 months; and in ice cubes after 3 months concerning molds. Regarding total coliforms $\left(\leq 10^{2}\right)$ and E. coli $(\leq 10)$, all samples were satisfactory according to Santos et al. (2005).

Taking into account these results, it is necessary to inform the flower suppliers that they must follow good hygiene and manufacture practices in order to guarantee the safety of their product. Even though freezing has caused a decrease in number of microorganisms in most of the situations, it is very important to guarantee that during storage, the temperature must remain constant without fluctuations. Furthermore, concerning the use of frozen flowers, these can be used straight frozen in bakery, ice creams, or other foods without thawing first. The flowers in ice cubes can be incorporated directly into beverages. If it is necessary to thaw the flowers, this must never be done at room temperature or in warm water, because it may endanger microbiological safety. In this sense, defrosting should be done in the refrigerator for the shortest possible time and then used. Furthermore, the flowers should not be refrozen because in addition to losing quality, they can lead to microbial growth.

\section{CONCLUSION}

Flowers preserved in ice cubes showed good visual appearance up to 3 months, whereas in frozen, in their natural form, it was only perceived up to 1 month, except for kalanchoe. No pattern in the studied bioactive compounds and antioxidant activity was observed between freezing treatments and time of storage. However, in general, flowers preserved in ice cubes for 3 months showed the lowest values of bioactive compounds and antioxidant activity. On the contrary for flowers frozen in their natural form, the contents of phenolic compounds (TRC, tannins, and flavonoids) maintained or increased during 1 month of storage, except borage. Concerning microbial quality, frozen flowers in their natural form and frozen in ice cubes decreased or maintained the levels of microorganisms when compared to fresh samples, except in dandelion. Thus, our results indicate that to maintain flowers for 3 months, preservation in ice cubes seems to be more appropriate, while for shorter times, as up to 1 month, freezing alone is also a good alternative. So, both freezing treatments can be regarded as interesting solutions to preserve edible flowers behind their flowering season. Furthermore, new uses and products may be developed for these frozen flowers, such as new drinks, cocktails, ice creams, and bakery products.

\section{ACKNOWLEDGMENTS}

The authors acknowledge the Portuguese Foundation for Science and Technology (FCT, Portugal) for the financial support provided by the research grant SFRH/BD/95853/2013 to Luana Fernandes and FCT/MCT for the financial support to QOPNA Research Unit (FCT UID/QUI/00062/2019) and LAQV Research Unit (UID/QUI/50006/2019) through national funds and cofinanced by the FEDER within the PT2020 Partnership Agreement. Furthermore, the authors are grateful to the Foundation for Science and Technology (FCT, Portugal) and FEDER under Programme PT2020 for financial support to CIMO (UID/AGR/00690/2019).

\section{AUTHOR CONTRIBUTIONS}

Conceptualization: Luana Fernandes, Elsa Ramalhosa, Jorge Saraiva, and Susana Casal.

Methodology: Luana Fernandes, Elsa Ramalhosa, and Ermelinda L. Pereira.

Investigation: Luana Fernandes.

Data curation: Luana Fernandes Elsa Ramalhosa; Ermelinda L.

Pereira, Jorge Saraiva Susana Casal, and José A. Pereira.

Writing and original draft preparation: Luana Fernandes.

Writing, review, and editing: Elsa Ramalhosa, Jorge Saraiva Susana Casal, and José A. Pereira.

Supervision: Elsa Ramalhosa, Jorge Saraiva, Susana Casal, and Jose.A. Pereira.

Project administration: Elsa Ramalhosa, Jorge Saraiva, and $\mathrm{Su}-$ sana Casal.

\section{CONFLICT OF INTEREST}

The authors declare that there is no conflict of interest.

\section{REFERENCES}

Asami, D. K., Hong, Y. J., Barrett, D. M., \& Mitchell, A. E. (2003). Comparison of the total phenolic and ascorbic acid content of freeze-dried and air-dried marionberry, strawberry, and corn grown using conventional, organic, and sustainable agricultural practices. Journal of Agricultural and Food Chemistry, 51, 1237-1241

Barriada-Bernal, L. G., Almaraz-Abarca, N., Delgado-Alvarado, E. A., Gallardo-Velázquez, T., Ávila-Reyes, J. A., Torres-Morán, M. I., ... Herrera-Arrieta, Y. (2014). Flavonoid composition and antioxidant capacity of the edible flowers of Agave durangensis (Agavaceae). CYTA - Journal of Food, 12, 105-114.

Benvenuti, S., Bortolotti, E., \& Maggini, R. (2016). Antioxidant power, anthocyanin content and organoleptic performance of edible flowers. Scientia Horticulturae, 199, 170-177.

Chen, G.-L., Chen, S.-G., Xi, Y.-Q., Chen, F, Zhao, Y.-Y., Luo, C.-X., \& Gao, Y.-Q. (2015) Total phenolic, flavonoid and antioxidant activity of 23 edible flowers subjected to in vitro digestion. Journal of Functional Foods, 17, 243-259.

Cohen, W., \& Fisher, J. (2012). The book of gardening projects for kids: 101 ways to get kids outside, dirty and having fun. Portland; London: Timber Press.

Delgado, T., Malheiro, R., Pereira, J. A., \& Ramalhosa, E. (2010). Hazelnut (Corylus avellana L.) kernels as a source of antioxidants and their potential in relation to other nuts. Industrial Crops and Products, 32, 621-626.

Dickens, D., Dupont. H., Johnson, P. (1985). Survival of bacterial enteropathogens in the ice of popular drinks. Journal of the American Medical Association, 252, 3141-3143.

Falcão, A., Chaves, E. S., Kuskoski, E. M., Fett, R., Falcão, L. D., \& Bordignon-Luiz, M. T. (2017). Total polyphenol index, total anthocyanins and antioxidant activity of a model system of grape jelly. Ciência e Tecnologia de Alimentos, 27, 637-642.

Fernandes, L., Casal, S., Pereira, J. A., Ramalhosa, E., \& Saraiva, J. (2017a). Effect of high hydrostatic pressure (HHP) on the quality of four edible flowers: Viola $\times$ wittrockiana, Centaurea cyanus, Borago officinalis and Camellia japonica. International Journal of Food Science \& Technology, 52(11), 2455-2462.

Fernandes, L., Casal, S., Pereira, J. A., Ramalhosa, E., \& Saraiva, J. (2017b). Optimization of high pressure bioactive compounds extraction from pansies (Viola $\times$ wittrockiana) by response surface methodology. High Pressure Research, 37, 415-425.

Fernandes, L., Casal, S., Pereira, J. A., Pereira, E., Saraiva, J., \& Ramalhosa, E. (2018). Effect of alginate coating on the physico-chemical and microbial quality of pansies (Viola $\times$ wittrockiana) during storage. Food Science and Biotechnology, 27(4), 987-996.

Fernandes, L., Casal, S., Pereira, J. A., Saraiva, J., \& Ramalhosa, E. (2018). Effects of different drying methods on bioactive compounds and antioxidant properties of edible Centaurea (Centaurea cyanus) petals. Brazilian Journal of Food Technology, 21, e2017211. 
Fernandes, L., Pereira, J. A., Baptista, P., Saraiva, J., Ramalhosa, E., \& Casal, S. (2018). Effect of application of edible coating and packaging on the quality of pansies (Viola $\times$ wittrockiana) of different colors and sizes. Food Science and Technology International, 24(4), 321-329.

Fernandes, L., Pereira, J. A., Saraiva, J., Casal, S., \& Ramalhosa, E. (2019). Extraction solvents' influence on the content of bioactive compounds and antioxidant activity of pansies. Millennium, 2(8), 89-99.

Garcia, E., \& Barrett, D. M. (2002). Preservative treatments for fresh-cut fruits and vegetables. In O. Lamikanra (Ed.), Fresh-cut fruits and vegetables: Science, technology and market (pp. 1-32). (Chapter 9). Boca Raton, FL: CRC Press.

Gounot, A. M. (1986). Psychrophilic and psychrotrophic microorganisms. Experientia, 42, 11921197.

Horrelson, W. (2003). Herbs, edible flowers and spices. In R. L. Underkoffler (Ed.), Living cuisine: The art of spirit of raw foods (pp. 127-129). New York: Penguin Group.

Koike, A., Barreira, J. C. M., Barros, L., Santos-Buelga, C., Villavicencio, A. L. C. H., \& Ferreira, I. C. F. R. (2015). Irradiation as a novel approach to improve quality of Tropaeolum majus L. flowers: Benefits in phenolic profiles and antioxidant activity. Innovative Food Science and Emerging Technologies, 30, 138-144.

Li, A.-N., Li, S., Li, H.-B., Xu, D.-P., Xu, X.-R., \& Chen, F. (2014). Total phenolic contents and antioxidant capacities of 51 edible and wild flowers. Journal of Functional Foods, 6, 319-330.

Loizzo, M. R., Pugliese, A., Bonesi, M., Tenuta, M. C., Menichini, F., Xiao, J., \& Tundis, R. (2016). Edible flowers: A rich source of phytochemicals with antioxidant and hypoglycemic properties. Journal of Agricultural and Food Chemistry, 64, 24672474.

Mlcek, J., \& Rop, O. (2011). Fresh edible flowers of ornamental plants - A new source of nutraceutical foods. Trends in Food Science \& Technology, 22, 561-569.

Nascimento, A. M. P., Paiva, P. D. O., Manfredini, G. M., \& Sales, T. S. (2019). Harvest stages and pulsing in ornamental sunflower 'Sunbright Supreme'. Ornamental Horticulture, 25, 149-157.

Newman, S. E., \& O'Connor, A. S. (2013). Edible Flowers. Colorado State University Extension, Fact Sheet No. 7.237, Colorado. Retrieved from www.ext.colostate.edu

Panavas, T., \& Rubinstein, B. (1998). Oxidative events during programmed cell death of daylily (Hemerocallis hybrid) petals. Plant Science, 133, 125-138.
Petzold, G., \& Moreno, J. (2016). Refrigeration and frozen preservation of vegetables. In Y. P. Hui \& O. Evranuz (Eds.), Handbook of vegetable preservation and processing (pp. 201-209). Boca Raton, FL: CRC Press.

Puupponen-Pimiä, R., Häkkinen, S. T., Aarni, M., Suortti, T., Lampi, A. M., Eurola, M., .. Oksman-Caldentey, K.-M. (2003). Blanching and long-term freezing affect various bioactive compounds of vegetables in different ways. Journal of the Science of Food and Agriculture, 83, 1389-1402.

Rickman, J. C., Barrett, D. M., \& Bruhn, C. M. (2007). Review nutritional comparison of fresh, frozen and canned fruits and vegetables. Part 1 . Vitamins $\mathrm{C}$ and B and phenolic compounds. Journal of the Science of Food and Agriculture, 87, 930-944.

Santos, M. I., Correia, C., Cunha, M. I. C., Saraiva, M. M., \& Novais, M. R. (2005). Valore Guia para avaliação da qualidade microbiológica de alimentos prontos a comer preparados em estabelecimentos de restauração. Revista da Ordem dos Farmacêuticos, 64, 66-68.

Skowyra, M., Calvo, M. I., Gallego, M. G., Azman, N. A. M., \& Almajano, M. P. (2014) Characterization of phytochemicals in petals of different colours from Viola $\times$ wittrockian Gams and their correlation with antioxidant activity. Journal of Agricultural Science, 6, 93-105.

Sousa, G. B., Tamagnini, L. M., Olmos, P. D. \& González, R. D. (2002). Microbial enumeration in ready-to-eat foods and their relationship to good manufacturing practice. Journal of Food Safety, 22, 27-3.

Tomsone, L., \& Kruma, Z. (2014). Influence of freezing and drying on the phenol content and antioxidant activity of horseradish and lovage. In FOODBALT, pp. 192-197.

Tanji, A., \& Nassif, F. (1995). Edible weeds in Marocco. Weed Technology, 9, 617-620.

Vescovo, M., Torriano, S., Orsi, C., Macchiarolo, F., \& Scolari, G. (1996). Application of antimicrobial-producing lactic acid bacteria to control pathogens in ready-to-use vegetables. Journal of Applied Bacteriology, 81, 113-119.

WHO (World Health Organization) (1997) Guidelines for Drinking Water Quality. Surveillance and Control of Community Supplies. Geneva, Switzerland: WHO.

Xiong, L., Yang, J., Jiang, Y., Lu, B., Hu, Y., Zhou, F., .. Shen, C. (2014). Phenolic compound and antioxidant capacities of 10 common edible flowers from China. Journal of Food Science, $79,517-525$. 